
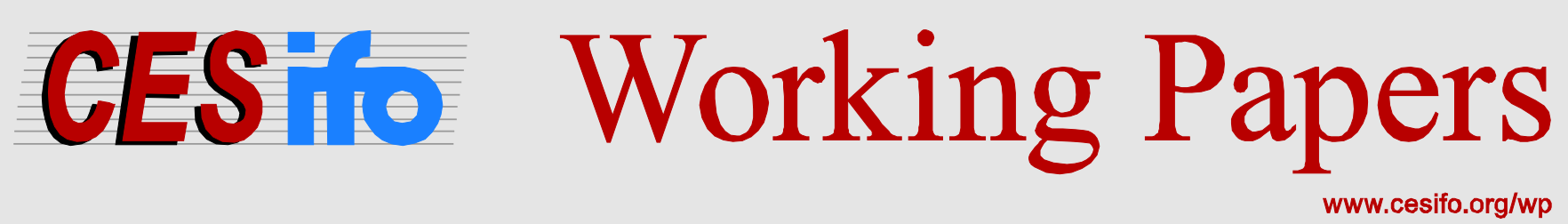

\title{
Does Giving to Charity Lead to Better Health? Evidence from Tax Subsidies for Charitable Giving
}

\author{
Barış K. Yörük
}

CESIFO WORKING PAPER NO. 4853

CATEGORY 1: PUBliC FINANCE

JUNE 2014

An electronic version of the paper may be downloaded

- from the SSRN website:

- from the RePEc website:

- from the CESifo website:

WWw.SSRN.com

www.RePEc.org

www.CESifo-group.org/wp

\section{CESifo}




\title{
Does Giving to Charity Lead to Better Health? Evidence from Tax Subsidies for Charitable Giving
}

\begin{abstract}
In the United States, charitable contributions can be deducted from taxable income making the price of giving inversely related to the marginal tax rate. The existing literature documents that charitable giving is very responsive to tax subsidies, but often ignores the spillover effects of such policies. On the other hand, a growing body of literature documents that giving to others reduces stress and strengthens the immune system, which results in better health and longer life expectancy. These findings imply that tax subsidies for charitable giving may have positive spillover effects on health. This paper investigates this hypothesis using data from Center on Philanthropy Panel Study (COPPS), the philanthropy module of the Panel Study Income Dynamics (PSID). Understanding the spillover effects of charitable subsidies on health is quite important given the existing literature that links health status to several important economic outcomes. The results show that charitable subsidies have positive spillover effects on health. In particular, the implied cross-price elasticity of health index with respect to giving is -0.13 . These results are robust to potential endogeneity of income and highlight the positive externalities created by tax subsidies for charitable giving.
\end{abstract}

JEL-Code: H240, H310, I100.

Keywords: charitable giving, health status, tax subsidies.

\author{
Barıș K. Yörük \\ Department of Economics \\ University at Albany, SUNY \\ 1400 Washington Ave \\ USA - Albany, NY 12222 \\ byoruk@albany.edu
}

May 3, 2014

I thank session participants at the 2014 ASSA Meetings and Jonathan Meer for helpful comments. 


\section{Introduction}

In the United States, charitable contributions are tax deductible. This policy makes a charitable donation less costly for those who itemize deductions in their federal or state income tax returns. According to the most recent estimate, the federal government was estimated to have 47 billion in foregone revenue in 2012 due to millions of households who itemized charitable deductions in their federal tax returns (Joint Committee on Taxation, 2010). The economic rationales for providing tax subsidies for charitable contributions are well-documented. ${ }^{1}$ The existing literature also documents that the amount of charitable contributions is very responsive to tax subsidies. However, the indirect effects of charitable subsidies are relatively unknown. ${ }^{2}$ In addition, recent studies in medicine and psychology document that giving to others leads to better health outcomes. This finding implies that tax subsidies for charitable giving may have positive spillover effects on health. In this paper, I investigate this hypothesis using data from a unique survey that contains information on charitable giving and several different health outcomes.

Understanding more about the determinants of health is quite important since an extensive literature links health with several important economic outcomes. For instance, Bhargava et al. (2001) and Bloom, Canning, and Sevilla (2001) show that health outcomes are associated with economic growth. Health is also a major determinant of several labor market outcomes. Grossman (1972) presents a model in which illness prevents work so that the cost of ill health is lost labor time. Stewart (2001) examines the impact of health status on the duration of unemployment spells and finds that individuals with impaired health will have significantly longer unemployment spells. Several studies also document the significant relationship between health and educational outcomes such as school attendance, cognitive ability, and learning. In particular, Bils and Klenow (2000) document the positive effect of good health on investments in education at the national level. Bleakley (2003) finds that deworming of children in the American South had a positive impact on their educational achievements while in school, whereas Miguel and Kremer (2004) show that deworming of children in Kenya increased school attendance. Health is also linked with saving decisions and demographic outcomes. ${ }^{3}$ Therefore, understanding the indirect effects of charitable

\footnotetext{
${ }^{1}$ Andreoni (2006) provides an extensive discussion of the relationship between charitable subsidies and giving.

${ }^{2}$ An exception is a handful of studies which investigate the spillover effects of charitable subsidies on volunteering and religious attendance. See, for example, Menchik and Weisbrod (1987), Brown and Lankford (1992), Feldman (2010), and Gruber (2004).

${ }^{3}$ Hurd, McFadden, and Gan (1998) show that increased expectation of longevity leads to greater wealth-holding at the household level in the United States. Using cross-country data, Bloom, Canning, and Graham (2003) find a positive effect of life expectancy on national savings. Schultz (1997) argue that reduced infant mortality, increased
} 
subsidies on health and health related outcomes are important and findings from empirical analysis may help policymakers to make informed choices about the spillover effects of charitable subsidies.

In order to investigate the relationship between charitable behavior and health, I use data from a household level survey which contains detailed information on charitable giving and several health outcomes for the household head: the philanthropy module of the Panel Study of Income Dynamics (PSID). A major difficulty in identifying the relationship between charitable behavior and health is the two-way causality between these two outcomes. I argue that tax subsidies for charitable contributions affect health status only through charitable giving and hence, they are exogenous to health once income and other household and individual level characteristics are controlled for. Therefore, following Gruber (2004) and Yörük (2013), I exploit the variation in the subsidization of charitable giving in the United States over time, across income levels, and across states and use the tax subsidy rate of giving as an instrument for the propensity to give and the amount of contributions in order identify the relationship between charitable behavior and several health outcomes. I expect that the subsidy rate should be positively correlated with charitable giving but uncorrelated with the unobserved variables that may affect health outcomes after income and several observable factors that are associated with charitable behavior and health are controlled for.

The results imply that tax subsidies have positive spillover effects on overall health status and decrease the probability of suffering from several health problems. In particular, a one percentage point increase in the subsidy to charitable giving leads to a 0.004 point increase in the health index. I also find that the estimated cross-price elasticity of health with respect to giving is -0.13 and that the tax subsidy for giving decreases the probability of suffering from a lung disease, emotional and psychological problems, and arthritis. Although tax subsidies have positive spillover effects on other health related problems such as high blood pressure, diabetes, cancer, heart attack, and obesity, these effects are not statistically significant. These results are robust to the potential endogeneity of income and the possible existence of omitted factors that vary jointly by income level and year, jointly by state and year, and jointly by state and income level. Using the subsidy rate for charitable giving as an instrument for charitable behavior, I also document the relationship between charitable behavior and health. I find that a one log point increase in the amount of charitable contributions is associated with approximately 0.085 point increase in the health index.

The rest of this paper is organized as follows. The next section presents a review of the existing numbers of surviving children, and rising wages for women can lower desired fertility. 
literature which documents the relationship between charitable behavior and health. Section three presents the data and discusses the empirical methodology. Section four discusses the results and presents several robustness checks. Section five provides a discussion of policy implications and concludes.

\section{Literature review}

\subsection{Tax subsidies and charitable behavior}

Tax subsidies for charitable giving is part of the US tax system and of other tax systems around the world. On the one hand, this policy reduces tax revenues. On the other hand, it decreases the effective price of charitable donations and hence, encourages more of it. Suppose that $t$ is the marginal tax rate faced by an individual. Each dollar given away to charity costs less than a dollar if this individual itemizes deductions in her tax return. Therefore, the effective price of a dollar worth of charitable donation is $1-t$ for those who itemize deductions and 1 for those who do not (Andreoni, 2006). If giving is price elastic, that is, if the price elasticity of giving is less than negative one, then the cost of allowing tax subsidies for charitable giving, measured in foregone tax revenues, is less than its benefit, measured by increased dollars of charitable giving. Therefore, as long as charitable giving is price elastic, tax subsidies for charitable giving are desirable.

There is a sizeable literature devoted to assessing the elasticity of charitable giving with respect to its after-tax price. Andreoni (2006) provides a detailed survey of theoretical and empirical studies in this literature. Earlier studies estimated elasticities of charitable giving with respect to its after-tax price of greater than minus one in absolute value (Clotfelter, 1985 and Steinberg, 1990). However, some recent studies find that charitable giving is price inelastic (Randolph, 1995 and Barrett, McGuirk, and Steinberg, 1997). The main empirical problem that is widely-discussed in the literature is the endogeneity of the after-tax price of giving. The most common approach to address this problem is to use the first-dollar tax price as an instrument for the after-tax price. ${ }^{4}$ In order to calculate the first-dollar price, one has to compute the reduction in taxes based on income, but assuming no existing charitable giving. An alternative approach is using state tax rates as an instrument for the after-tax price. However, Feenberg (1987) argues that differences in charitable subsidies across individuals are correlated with other factors that may determine tastes

\footnotetext{
${ }^{4}$ In the empirical analysis, I use the after-tax price in order to estimate the cross-price elasticity of health with respect to giving. Although not reported in the paper, estimating models using the first-dollar price instead of the after-tax price yields similar results.
} 
for charitable giving. Furthermore, states that adopt different tax rates may differ systematically in unobserved ways and these unobserved differences may also affect both the marginal tax rates and charitable behavior. In this paper, following Gruber (2004), I rely on the extensive variation over time, within income levels, and within states to control for both income and fixed state differences in identifying the effect of tax subsidies for charitable giving.

\subsection{Health benefits of charitable behavior}

There is an extensive literature that links generosity and giving to others with better health outcomes. The existing medical studies suggest that giving to others reduces the stress and strengthens the immune system, which results in better health and a longer life expectancy. For instance, McClelland and Kirshnit (1988) find that the act of thinking about generosity significantly increases the protective antibody salivary immunoglobulin A, a protein used by the immune system to identify and neutralize foreign objects such as bacteria and viruses. Similarly, Dunn et al. (2010) document that keeping money instead of giving to others increases the level of cortisol, a hormone released in response to stress and low level of blood glucocorticoids.

Volunteering is also linked with better health outcomes. Field et al. (1998) find that volunteering is associated with less anxiety and depression, as well as improved health and a reduction in stressrelated hormones for older people. Similarly, using survey data, Musick and Wilson (2003) show that volunteering significantly reduces depression. Thoits and Hewitt (2001) document that people who volunteer are more likely to be happier and experience better physical health and less depression. Arnstein et al. (2002) investigate the effect of volunteering on chronic pain patients. Their findings

show that volunteering decreases pain, depression, and disability. Furthermore, these effects are stable in the long-run. Moen, Dempster-McClain, and Williams (1989) use a panel data set that follow 427 wives and mothers who lived in upstate New York for 30 years. They find that even after controlling for several observable personal characteristics and adjusting for baseline health status, those women who engaged in volunteer work to help other people at least once a week lived longer and had better physical functioning. Oman, Thoresen, and McMahon (1999) and Harris and Thoresen (2005) also confirm this finding and document that volunteering is associated with a longer life expectancy.

Recent literature also shows that giving money to charity leads to similar activity in brain regions implicated in the experience of pleasure and reward. Using functional magnetic resonance imaging (MRI), Harbaugh, Mayr, and Burghart (2007) show that giving charity leads to activation 
in ventral striatum, a brain region associated with the value of a range of rewarding stimuli such as art or attractive faces. Similarly, Moll et al. (2006) show that the parts of the brain that are activated when money is given to an individual are also activated when money is donated. These results suggest that giving is inherently rewarding.

Furthermore, a handful of studies show that charitable behavior leads to happiness. Using data from German Socioeconomic Panel, Meier and Stutzer (2008) show that volunteering increases life satisfaction and happiness. Lyubomirsky, Tkach, and Sheldon (2004) demonstrate that simply asking people to commit random acts of kindness can significantly increase happiness levels for several weeks. Finally, Dunn, Aknin, and Norton (2008) show that individuals who devote more money to prosocial spending report greater happiness, whereas personal spending is unrelated to happiness.

However, to my best knowledge, none of the studies in the existing literature attempt to document the spillover effects of charitable subsidies on health. In this paper, I first document the spillover effects of tax subsidies for charitable giving on several health outcomes. Next, I show that the exogeneous variation in charitable subsidies can also be used to identify the relationship between charitable giving and health.

\section{$3 \quad$ Data and empirical strategy}

For the empirical analysis, I use 2001, 2003, 2005, and 2007 waves of the Center on Philanthropy Panel Study (COPPS), the philanthropy module of the PSID. The COPPS contains detailed information on household giving and various indicators of relevant motivations. Wilhelm (2006, 2007) argues that the quality of the COPPS data may be superior to that collected in other household surveys of charitable giving because of the PSID staff's experience in collecting data and the respondents' experience with the survey procedure. The unique feature of this data set is that it contains information on the self-reported health status of the household head and on several health problems that she has suffered from. Individuals' judgment about their health status may be subjective. However, previous studies have documented that people's perception of their own health is a good predictor of future health-care use and of mortality rates. For instance, Idler and Benyamini (1997) find that good-to-excellent self-reported health status is associated with lower risk of mortality, whereas McCallum et al. (1994) show that poor self-reported health status is a good predictor of subsequent illness and premature death. Furthermore, the main identifying 
assumption in the empirical analysis is that the tax subsidies for giving affect health only through charitable contributions. Therefore, the estimates from the empirical models should yield a consistent effect of tax subsidies on health unless people who misreport their health status systematically tend to sort themselves to lower or higher tax brackets.

Following Wilhelm (2006), I use only PSID's nationally representative sample designed by the Survey Research center (SRC sample) for the empirical analysis. Pooling data from four waves of the COPPS yields 17970 observations. Table 1 provides the description and summary statistics of the key variables used in the empirical analysis. On average, $69 \%$ percent of the households reported contributing to charity with and average contribution of $\$ 1527$ in 2007 dollars. Alternatively, on average, people give $1.9 \%$ of their income to charitable organizations. The average tax subsidy rate to charitable giving in the sample is $12.1 \%$. These estimates are comparable with the estimates from other sources of charitable giving data. ${ }^{5}$

In the COPPS, the household heads were asked the following question: "Would you say your health in general is excellent, very good, good, fair, or poor?". The distribution of answers to this question is fairly broad. Table 2 shows that approximately $13 \%$ of household heads reported poor or fair, $27 \%$ reported good, and $60 \%$ reported very good or excellent health status. In line with earlier findings, when asked to rate their own health, female household heads, on average, report being in worse health than male household heads do. While the traditional explanation for this finding is that women's lower self-rated health is simply a reporting bias, a recent study suggests that women have a higher rate of chronic diseases and hence, more likely to report worse health than men do (Malmusi et al., 2012). Similarly, Table 2 also shows that black or unmarried household heads tend to report being in worse health than white or married household heads do.

For the basic empirical analysis, I simply use the linear index formed by the responses to the health status question as a dependent variable with values 5 through $1 .^{6}$ Hence, in this basic analysis, I assume that there are equal impacts of each unit change in the self-reported health

\footnotetext{
${ }^{5}$ These estimates are comparable with data from other surveys. For example, in the 1992, 1994, 1996 , and 2001 waves of Survey of Giving and Volunteering in the United States, on average, people donate $2.2 \%$ of their income to charity. Gruber (2004) reports that the average tax subsidy to charitable giving, factoring in the odds of itemization by income is $9.4 \%$ in Consumer Expenditure Survey, and 10\% in General Social Survey. I estimate that the average subsidy in the 2001 edition of Survey of Giving and Volunteering in the United States is 11.2\%. The slightly higher subsidy rates on average in the PSID may be due to the higher levels of average income in this data set.

${ }^{6}$ In the COPPS, the answers to health status question is orginally coded as follows: 1=Excellent, 2-Very good, 3-Good, 4-Fair, 5-Poor. I recode the answers as follows: 5-Excellent, 4-Very good, 3-Good, 2-Fair, 1-Poor so that an increase in the health status index implies an improvement in health. In the empirical analysis, this recoded variable is used.
} 
index. However, I also estimate alternative probit and ordered probit models that control for the ordinal nature of this variable.

\subsection{The after-tax price of giving}

In the Unites States, households are allowed to itemize charitable deductions in their federal and state income tax returns. Therefore, each dollar given away to charity costs less than a dollar if the household itemizes deductions. Following the existing literature, I first compute the after-tax price of giving, which incorporates charitable contributions, as $1-t$ for those who itemize deductions and 1 for those who do not, where $t$ is the sum of the federal and state marginal tax rates that the donor faces. Next, following Gruber (2004), I calculate the tax subsidy rate for charitable giving as one minus the after-tax price. PSID contains information on whether the household itemized deductions or not. In order to calculate the marginal tax rates for each household at a given year, I use National Bureau of Economic Research (NBER)'s TAXSIM model (version 9.0). ${ }^{7}$ TAXSIM model inputs information on income, state of residence, marital status, number of children, age, child care expenses, itemized deductions such as charitable donations and health care expenses, mortgage interest payments, and property taxes or rent paid and outputs federal and state marginal tax rates for each household. The information on all these variables are available in the PSID. ${ }^{8}$

The resulting after-tax prices of giving vary across the households primarily due to the differences in income, state of residence, and time. For instance, high-income taxpayers have relatively higher marginal tax rates, and hence a more sizeable reduction in their tax burden from deductions to their taxable income. There have been significant changes in the schedule of tax rates from 2001 to 2007 at the federal and state level, which are incorporated into the calculation of the marginal tax rates. For instance, in 2002, tax rates above the $15 \%$ bracket dropped by one-half percentage point. The 2002 tax tables also incorporated for the first time a new $10 \%$ tax bracket. In addition to several new deductions and credits introduced during this period, tax rates above the $15 \%$ were dropped by another 2 percentage points in 2003, new reporting requirements for non-cash charitable contributions were introduced in 2004. Income based limits for cash charitable donations were

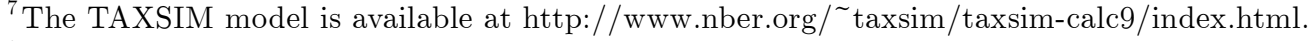

${ }^{8}$ Following Duncan (1999), Andreoni, Brown, and Rischall (2003), Yörük (2009), and Yörük (2010), I assumed that those who are married report joint filing status. Following Reinstein (2010), I include the mortgage interest payment for the first mortgage and ignore the second and the third mortgages. In addition to charitable giving, I also incorporate other deductions such as health care costs. Reinstein (2010) provides a detailed discussion of the computation of the marginal tax rates for the PSID with TAXSIM model.
} 
lifted in 2005. In 2006, new rules for giving to charity were introduced. To deduct any charitable donation of money, taxpayers were required to have a bank record or a written communication from the recipient showing the name of the organization and the date and amount of the contribution. ${ }^{9}$

Finally, tax subsidies to charity may vary across states due to the considerable variation in state income tax systems. A number of states follow the federal tax laws, so that charitable contributions are fully deductible for itemizers, while some others ask taxpayers to explicitly report their federally itemized amounts from their state taxable income. Furthermore, several states do not allow a deduction for charitable contributions. Each of these factors, income, time, and state, may be independently correlated with both charitable behavior and health outcomes. In addition to several other demographic variables, the empirical models explicitly control for the effects of these variables.

\subsection{Empirical strategy}

The basic empirical model follows that of Gruber (2004) and Yörük (2013), who investigated the effect of charitable subsidies on religious behavior. Let Charity denote the probability of giving or the amount of charitable contributions. The relationship between charitable behavior and health can be expressed as follows:

$$
\text { Health }_{i s t}=\beta_{1}^{\prime} X_{i s t}+\gamma_{1} \text { Inc }_{i s t}++\alpha \text { Charity }_{i s t}+\text { State }_{s}+\text { Year }_{t}+\epsilon_{i s t}
$$

where Health denotes the respondent's self-reported health status, $X$ is a set of demographic control

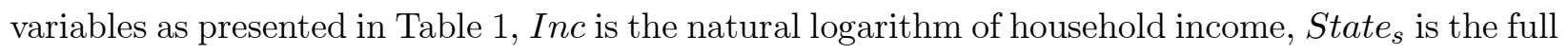

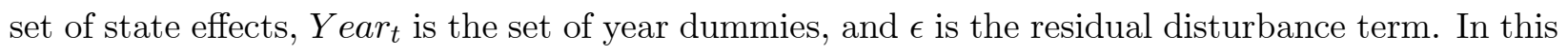
model, if some unobservable characteristics of respondents that may be associated with their health status are also correlated with their giving behavior, then one cannot estimate the consistent effect of charitable behavior on health. The existing literature shows that tax subsidies for charitable giving positively affect charitable behavior. Therefore, charitable giving can be expressed as a function of income, observable characteristics of the households, and the rate of the tax subsidy that they are subject to. Suppose that tax subsidies for charitable giving affect health status only through the decision to give or the amount of charitable contributions. Then, in order to estimate the spillover effects of tax subsidies for charitable giving on health, one can estimate a reduced

\footnotetext{
${ }^{9}$ IRS regularly publishes highlights of tax law changes for each tax year. For further details of law changes during the 2001-2007 period, one can refer to www.irs.gov.
} 
form model of the following form:

$$
\text { Health }_{i s t}=\beta_{2}^{\prime} X_{i s t}+\gamma_{2} \text { Inc }_{i s t}+\lambda \text { Subs }_{\text {ist }}+\text { State }_{s}+\text { Year }_{t}+v_{\text {ist }}
$$

where $S u b s$ is the subsidy rate for charitable giving and $v$ is the residual disturbance term that is assumed to be uncorrelated with $X$ 's, Inc, Subs, State $s$, and Year ${ }_{t}{ }^{10}$ This model controls for direct effects of income, state of residence, and time. However, as a robustness check, I also estimate models that control for the interactions of income, state, and year, and that address the possible endogeneity of income and the ordinal nature of the outcome variable. In order to estimate the relationship between charitable behavior and health, i.e., equation (1), I use two stage least squares (2SLS). In these models, I use subsidy rate for charitable giving as an instrument for the probability of giving and the amount of charitable contributions in the first stage.

\section{Results}

\subsection{The effect of charitable subsidies on health status}

In order to estimate the effect of tax subsidies for charitable giving on self-reported health status, I estimate the reduced form model in equation (2). The results from this main model are reported in the first column of Table 3. For the full sample, health index increases by 0.004 units for each one percentage point subsidy to charitable giving. The mean of this variable is 3.67 with a standard deviation of 1.04. Therefore, the same magnitude of an increase in the subsidy is associated with approximately $0.1 \%$ improvement in health status from its mean or alternatively $0.4 \%$ improvement of a standard deviation in this variable. This effect is highly significant. Since, on average, female household heads report being in worse health than male household heads do, I estimate separate regressions for female and male household heads. A one percentage point increase in the tax subsidy increases the health status of male heads by 0.003 points. Female heads are more responsive to charitable subsidies. For this group, the same magnitude of an increase in the tax subsidy is associated with a 0.005 unit increase in the health status index. Similar differences also exists between white and black household heads. While each percentage point increase in the tax subsidy improves the health status of white heads by 0.003 points, its effect on black heads is much larger. The health index for black heads raises by 0.005 points as a response to each percentage

\footnotetext{
${ }^{10} \mathrm{I}$ also estimate models without controlling for the state fixed effects. The estimates from these models are very similar to those presented in this paper. This suggests that although there exists differences in the tax rates at the state level, the main source of identification in empirical models is the changes in federal tax laws over time.
} 
point increase in the tax subsidy for charitable giving. In the COPPS, while charitable giving is reported at the household level, the information on health status is collected at the individual level. Therefore, I also estimate a separate regression for unmarried household heads. For this group, the effect of charitable subsidies on health remains to be positive and highly significant. In particular, for unmarried household heads, a one percentage point increase in the subsidy rate for charitable giving is associated with a 0.004 point increase in the health status. ${ }^{11}$

The second column in Table 3 shows that the implied cross-price elasticity of health index with respect to giving is $-0.13 .{ }^{12}$ Similarly, for male household heads, a one percent increase in the aftertax price is associated with a $0.11 \%$ deterioration in health. The estimated cross-price elasticities of health with respect to charitable giving for female, white, black, and unmarried household heads are statistically significant and differ between -0.12 and -0.16 . These results highlight the positive spillover effects of tax subsidies for charitable giving on health.

\subsubsection{Robustness checks}

Non-linearity of health index and income The results presented above rely on the implicit assumption that health status index is linear. This assumption may not be valid since these findings may be due to the changes in behavior at few particular points and may not reflect the changes throughout the distribution of different health status choices. I investigate this potential problem in Table 4. In the first two columns, I report the marginal effect of the subsidy rate from five separate regressions that use dummies for each of the five possible responses to the health status question as dependent variables. The results clearly show that charitable subsidies have a significant impact throughout the distribution of health status. In particular, as a response to a tax subsidy for charitable giving, there is a sizeable rise in the odds of reporting an excellent health status and a sizeable decline in the odds of reporting a poor health status. When I estimate alternative models in which I use the log of the after-tax price of giving instead of the subsidy rate, I find similar results. When the after tax price of giving rises and giving becomes more expensive, the probabilities of reporting excellent or very good health decrease, whereas the probabilities reporting fair or poor health significantly increase. The last two columns in Table 4 report the results from

\footnotetext{
${ }^{11}$ Although not reported, I also estimate a model for single-person households. I find that for this group, as a response to a one percentage point increase in charitable subsidies, the health status of the individual improves by 0.003 points.

${ }^{12}$ In order to estimate the cross-price elasticities, I estimate a model similar to equation (2). In this reduced form model, I simply substitute the subsidy rate with the log of the after-tax price. The cross-price elasticity of health with respect to charitable giving is calculated using the coefficient estimates from this model.
} 
an ordered probit model. These results also confirm the findings from the main model and show that charitable subsidies have a significant impact throughout the distribution of health status.

In the main empirical model, I assumed that the relationship between income and health status is linear. In alternative models, following Gruber (2004), instead of using the survey reported income, I use a set of ten dummy variables for the deciles of the income distribution to control nonparametrically for income distribution effects on health. The first specification in Table 5 presents the results from these alternative models. The estimated coefficient on the subsidy rate suggests that health index increases by 0.003 units for each one percentage point subsidy to charitable giving. Similarly, the implied cross-price elasticity of health index with respect to giving is -0.11 . Compared with the results from the main models, these results are very similar.

Endogeneity of income Another potential concern with the main empirical model is the endogeneity of incomes to health status. For instance, if poor health status is associated with a reduction in time available to generate income, this could decrease the subsidy to charitable giving and impose a bias to main estimates. Alternatively, if those who report excellent or very good health status are more likely to earn more, this could raise the tax subsidy to charitable giving and impose a positive bias to the relationship reported in Table 3. In order to address these potential concerns, I follow two different approaches. First, following Gruber (2004), I estimate alternative models using predicted income to compute the after-tax price of giving instead of the actual income. For this, I first predict household income based on the exogenous characteristics included in the empirical models such as age, gender, race, marital status, educational attainment, homeownership and employment status of the household head, family size, and the number of children in the household. I then use this predicted income to calculate marginal tax rates in the same fashion as with actual income. ${ }^{13}$ The second specification in Table 5 reports the results from this approach. The impact of the charitable subsidies on health remains to be positive and highly significant and is also very similar to the comparable estimates from the main model. Furthermore, the cross-price elasticity estimate from this alternative model is -0.12 , which is comparable to the elasticity estimate from the main model.

As an alternative approach, I follow Auten and Carroll (1999) and Gruber and Saez (2002) and exploit the exogenous changes in the marginal tax rates for a given income. That is, I estimate the change in tax price for each individual by holding income constant in 2001 and estimate the

\footnotetext{
${ }^{13}$ I use TAXSIM model to calculate the marginal tax rates with this alternative measure of income.
} 
tax price in each period at the same income level. Since income is held fixed across different time periods, changes in the tax price for each individual is due to changes in tax policy over time and the tax price change is truly exogenous with respect to each individual. The third specification in Table 5 reports the results from this alternative approach. The estimated coefficient on the subsidy rate implies that as a response to a one percentage point increase in the subsidy to charitable giving, health index rises by 0.004 points. Furthermore, in this model, the estimated cross-price elasticity of health with respect to giving is -0.13 . These results are comparable with the estimates from the main model and suggest that the estimated effect of charitable subsidies on health is robust to the potential endogeneity of income.

Omitted factors The remaining specifications reported in Table 5 address the potential omitted factors that may be correlated with both charitable subsidies and health status. These models include interactions between income and year, state and year, and state and income as additional controls. The interaction between household income and year captures any potential national shocks that may have occurred over time and that may have a heterogenous effect on different income levels. Inclusion of this interaction term slightly increases the estimated impact of charitable subsidies on health. The interactions between state and year dummies absorb any changes in states over time that has the same impact on all income levels. Again, inclusion of these interaction terms to the main model slightly increases the key coefficient on the subsidy rate for giving. The interaction dummies between income and each state dummy captures any differences in health status by income level across states. In this model, compared with the full sample results presented in Table 3, the estimated impact of subsidy rate and the cross-price elasticity of health with respect to giving remain virtually the same. ${ }^{14}$

\subsubsection{Alternative health related outcomes}

In addition to overall health status, PSID contains information on several health problems that the household head may have suffered from. In particular, household heads are asked whether they have ever been diagnosed with one or more of the following: a stroke, high blood pressure, diabetes, cancer, lung disease, heart attack, heart disease, emotional or psychiatric problems, arthritis, and asthma. PSID also contains information on weight and height of the household head. Using this

\footnotetext{
${ }^{14} \mathrm{I}$ also estimate an alternative model that includes all three interaction terms jointly. This model also yields comparable estimates with the main model.
} 
information, I calculate the body mass index (BMI) for each household head and identify those who are obese (BMI> 30). Given the positive effect of the tax subsidies on health, one would expect that the probability of suffering from one of these health problems or being an obese should decrease as a response to an increase in the subsidy rate for giving. In Table 6, I report the estimates from probit models in which the outcome variable is whether the household head suffered from one of these particular health problems. As expected, the estimated marginal effects of the subsidy rate for charitable giving on each individual health problem imply that charitable subsidies decrease the probability of suffering from a lung disease, emotional problems, and arthritis. Although tax subsidies have positive spillover effects on other health related problems such as high blood pressure, diabetes, cancer, heart attack, and obesity, these effects are not statistically significant.

\subsection{The effect of charitable giving on health}

So far, I presented the results from several reduced form models that document the positive spillover effects of charitable subsidies on health. In this section, I investigate the relationship between charitable giving and health status using the subsidy rate for giving as an instrument for charitable behavior. I report results from two stage least squares (2SLS) models. In these models, the main identifying assumption is that subsidy rate for giving affects health status only through the probability of giving or the amount of charitable contributions. ${ }^{15}$ Therefore, in order to be used as an instrumental variable, subsidy rate should satisfy two conditions. First, it must be a significant determinant of charitable behavior. Second, it must be uncorrelated with the unobserved covariates that may affect health status. Although one cannot test whether the second condition is satisfied, Table 7 clearly shows that in the first stage regressions, the tax subsidy rate for charitable giving is a significant determinant of the probability of giving and the amount of charitable contributions.

I start with investigating the impact of the probability of giving on health status. The results from the 2SLS models reported in Table 7 suggest that compared with those who do not give to charity, the health index of those who donate to a charitable organization is on average 0.83 points ( $79 \%$ of a standard deviation in the health index) higher. The relationship between the probability of giving and health remains to be positive and statistically significant for male, female, white, black, or unmarried household heads as well. Furthermore, compared with the ordinary least squares (OLS) estimates, which treat the probability of giving exogeneous, estimates from the 2SLS models are considerably larger.

\footnotetext{
${ }^{15}$ In these models, the dependent variable is the self-reported health index as described in the text and Table 1.
} 
The last three columns of Table 7 document the effect of the amount of charitable contributions on health status. The results from the 2SLS models show that a one log point increase in the amount of charitable contributions is associated with approximately 0.085 (8.1\% of a standard deviation in the health index) point increase in the health index. Compared with other groups, the impact of the amount of charitable donations on health is relatively larger for female heads. As in the impact of the probability of giving on health status, compared with the estimates from the OLS models, the effect of the amount of charitable contributions on health status is considerably larger in the 2SLS models.

Table 8 provides the results from similar models estimated for alternative health related outcomes. The results show that charitable behavior decreases the probability of being diagnosed with high blood pressure, lung disease, and arthritis significantly. Giving to charity has also positive impact on other health problems such as diabetes, cancer, heart attack, heart disease, emotional and psychological problems, and obesity. However, these effects are not statistically significant. ${ }^{16}$

\section{Discussion of results and conclusion}

Policymakers promote tax reliefs for charitable donors who itemize their donations in their federal and state tax returns. It has been well-documented in the literature that such policies are quite effective in increasing charitable contributions. However, the existing literature often ignores the indirect effects of tax subsidies on giving related outcomes. Recently, several medical studies document that giving to others reduces the stress and strengthens the immune system, which results in better health and a longer life expectancy. This finding implies that tax subsidies for charitable giving may have positive spillover effects on health. In this paper, I investigate this hypothesis using the COPPS, a unique data set that contains information on charitable contributions and several health outcomes.

I find that tax subsidies for charitable giving have positive spillover effects on overall health status and decreases the probability of suffering from several important health problems. In particular, my estimates suggest that the implied cross-price elasticity of health index with respect to giving is -0.13. Furthermore, charitable subsidies decrease the probability of suffering from a lung disease,

\footnotetext{
${ }^{16}$ In these models, in the first stage, the subsidy rate for giving is the instrument for the decision to give and the amount of charitable contributions. Since these are linear models, the coefficients on the tax subsidy in the first stage regressions are the same as the coefficients that are reported for the full sample in Table 7. Alternatively, I also estimate an IV-Probit type model for each individual outcome. Results from these alternative models are similar compared with those reported in Table 8 and are available upon request.
} 
emotional and psychological problems, and arthritis. Although tax subsidies reduce the probability of suffering from other health related problems such as high blood pressure, diabetes, cancer, heart attack, and obesity, the effect of subsidies on these outcomes is not statistically significant. These results are also robust under several alternative models that control for the potential endogeneity of income and the possible existence of several omitted factors that vary jointly by state and income, by state and year, and by income and year.

I also use the tax subsidies for charitable giving as an instrument for identifying the direct relationship between charitable behavior and health. I find that compared with non-donors, the health index of charitable donors is on average 0.83 points higher and that a one log point increase in the amount of charitable contributions is associated with approximately 0.085 point increase in the self-reported health index. Giving to others also decreases the probability of suffering from high blood pressure, lung disease, and arthritis significantly.

The results of this paper highlight the positive externalities created by charitable subsidies and provide insights for alternative theoretical or empirical models which may investigate the indirect effects of charitable subsidies on other economic outcomes. The results of this paper also suggest that further expansions in the subsidy to charitable giving would increase the amount of charitable donations and at the same time, would also positively affect the health status of the individuals

in the United States. Although, this paper provides some evidence that the improvement in the health status may be due to the positive effect of charitable subsidies on certain health problems, further research is needed to establish this relationship. Future work on similar topics would help further our understanding of the indirect impacts of tax subsidies for charitable giving and the relationship between giving behavior and related outcomes.

\section{References}

[1] Andreoni, J., E. Brown, and I. Rischall, 2003, Charitable giving by married couples: Who decides and why does it matter?, Journal of Human Resources, 38, 111-133.

[2] Andreoni, J., 2006, Philanthropy, Handbook of Giving, Reciprocity and Altruism, S-C. Kolm and J. Mercier Ythier, eds., Elsevier, Amsterdam, North Holland, 1201-1269.

[3] Arnstein, P. et al., 2002, From chronic pain patient to peer: Benefits and risks of volunteering, Pain Management Nursing, 3, 94-103. 
[4] Auten, G. and R. Carroll, 1999, The effect of income taxes on household income, Review of Economics and Statistics, 81, 681-693.

[5] Barrett, K.S., A.M. McGiurk, and R. Steinberg, 1997, Further evidence on the dynamic impact of taxes on charitable giving, National Tax Journal, 50, 321-334.

[6] Bhargava, A., D. Jamison, L. Lau, and C. Murray, 2001, Modelling the effects of health on economic growth, Journal of Health Economics, 20, 423-440.

[7] Bils, M. and P. J. Klenow, 2000, Does schooling cause growth?, American Economic Review, 90, 1160-183.

[8] Bleakley, H., 2003, Disease and development: Evidence from the American South, Journal of the European Economic Association, 1, 376-86.

[9] Bloom, D., D. Canning, and J.P. Sevilla, 2001, The Effect of Health on Economic Growth: Theory and Evidence, NBER Working Paper, No. 8587.

[10] Bloom, D. E., D. Canning, and B. Graham, 2003, Longevity and life-cycle savings, Scandinavian Journal of Economics, 105, 319-38.

[11] Brown, E. and H. Lankford, 1992, Gifts of money and time: Estimating the effects of tax prices and available time, Journal of Public Economics, 47, 321-341.

[12] Clotfelter, C.T., 1985, Federal tax policy and charitable giving, University of Chicago Press, Chicago, IL.

[13] Duncan, B., 1999, Modelling charitable contributions of time and money, Journal of Public Economics, 72, 213-242.

[14] Dunn, E.W., L.B. Aknin, and M.I. Norton, 2008, Spending money on others promotes happiness, Science, 319, 1687-1688.

[15] Dunn, E.W. et al., 2010, On the costs of self-interested economic behavior: How does stinginess get under the skin?, Journal of Health Psychology, 15, 627-633.

[16] Feenberg, D., 1987, Are tax price models really identified: The case of charitable giving, National Tax Journal, 40, 629-633. 
[17] Feldman, N.E., 2010, Time is money: Choosing between charitable activities, American Economic Journal: Economic Policy, 1, 103-130.

[18] Field, T.M. et al., 1998, Elder retired volunteers benefit from giving message therapy to infants, Journal of Applied Gerontology, 17, 229-239.

[19] Grossman, M.,1972, On the concept of health capital and the demand for health, Journal of Political Economy, 80, 223-255.

[20] Gruber, J., 2004, Pay or Pray? The impact of charitable subsidies on religious attendance, Journal of Public Economics, 88, 2635-2655.

[21] Gruber, J. and E. Saez, 2002, The elasticity of taxable income: Evidence and implications, Journal of Public Economics, 84, 1-32.

[22] Harbaugh, W.T., U. Myer, D.R. Burghart, 2007, Neural responses to taxation and voluntary giving reveals motives for charitable donations, Science, 316, 1622-1625.

[23] Harris, A. and C. Thoresen, 2005, Volunteering is associated with delayed mortality in older people: Analysis of the Longitudinal Study of Aging, Journal of Health Psychology, 10, 739752.

[24] Hurd, M., D. McFadden, and L. Gan, 1998, Subjective survival curves and life-cycle behavior, In Inquiries in the Economics of Aging, D. Wise (eds.), Chicago, University of Chicago Press.

[25] Idler, E.L. and Y. Benyamini, 1997, Self-rated health and mortality: A Review of twenty-seven community studies, Journal of Health and Social Behavior, 38, 21-37.

[26] Joint Committee on Taxation, 2010, Estimates of Federal Tax Expenditures for Fiscal Years 2010-2014, U.S. Government Printing Office, Washington, DC.

[27] Lyubomirsky, S., C. Tkach, and K.M. Sheldon, 2004, Pursuing sustained happiness through random acts of kindness and counting one's blessings: Tests of two six-week interventions, Unpublished Manuscript, Department of Psychology, University of California, Riverside.

[28] Malmusi, D. et al., 2012, Perception or real illness? How chronic conditions contribute to gender inequalities in self-rated health, European Journal of Public Health, 22, 781-786. 
[29] McCallum, J. et al., 1994, Self-reported health and survival: A 7-year follow-up study of Australian elderly, American Journal of Public Health, 84, 1100-1105.

[30] McClelland, D.C. and C. Kirshnit, 1988, The effect of motivational arousal through films on salivary immunoglobulin A, Psychology and Health, 2, 31-52.

[31] Meier, S. and A. Stutzer, 2008, Is volunteering rewarding in itself?, Economica, 75, 39-59.

[32] Menchik, P. and B.A. Weisbrod, Volunteer Labor Supply, 1987, Journal of Public Economics, $32,159-183$.

[33] Miguel, E. and M. Kremer, 2004, Worms: Identifying impacts on education and health in the presence of treatment externalities, Econometrica, 72, 159-217.

[34] Moll et al., 2006, Human fronto-mesolimbic networks guide decisions about charitable donation, Proceedings of the National Academy of Sciences, 103, 15623-15628.

[35] Moen P., D. Dempster-McClain, and R.M. Williams, 1989, Social integration and longevity: An event history analysis of women's roles and resilience, American Sociological Review, 54, 635-647.

[36] Musick, M.A. and J. Wilson, 2003, Volunteering and depression: The role of psychological and social resources in different age groups, Social Science $\&$ Medicine, 56, 259-269.

[37] Oman, D., C. Thoresen, and K. McMahon, 1999, Volunteerism and mortality among the community dwelling elderly, Journal of Health Psychology, 4, 301-316.

[38] Randolph, W.C., 1995, Dynamic income, progressive taxes, and the timing of charitable contributions, Journal of Political Economy, 103, 709-738.

[39] Reinstein, D., 2010, Does one charitable contribution come at the expense of another?, B.E. Journal of Economic Analysis and Policy (Advances), 11, Article 40.

[40] Schultz, T. P., 1997, The Demand for Children in Low Income Countries, In Handbook of Population and Family Economics, Vol. 1A, M.R. Rosenzweig and O. Stark (eds.), Amsterdam, North-Holland.

[41] Steinberg, R., 1990, Taxes and giving: New findings, Voluntas, 1, 61-79. 
[42] Stewart, J.M., 2001, The impact of health status on the duration of unemployment spells and the implications for studies of the impact of unemployment on health status, Journal of Health Economics, 20, 781-796.

[43] Thoits, P.A. and L.N. Hewitt, 2001, Volunteer work and well-being, Journal of Health and Social Behavior, 42, 115-131.

[44] Wilhelm, M., 2006, New data on charitable giving in the PSID, Economics Letters, 92, 26-31.

[45] Wilhelm, M., 2007, The quality and comparability of survey data on charitable giving, Nonprofit and Voluntary Sector Quarterly, 36, 65-84.

[46] Yörük, B.K., 2009, How responsive are charitable donors to requests to give?, Journal of Public Economics, 93, 1111-1117.

[47] Yörük, B.K., 2010, Charitable giving by married couples revisited, Journal of Human Resources, 45, 497-516.

[48] Yörük, B.K., 2013, The impact of charitable subsidies on religious giving and attendance: Evidence from panel data, Review of Economics and Statistics, 95, 1708-1721. 
Table 1. Definition of key variables and summary statistics

\begin{tabular}{|c|c|c|c|}
\hline Variable name & Definition & Mean & S.D. \\
\hline Give & $\begin{array}{l}=1 \text { if the household contributed money to charitable } \\
\text { organizations during the survey year. }\end{array}$ & 0.685 & 0.464 \\
\hline Contribution & $\begin{array}{l}\text { Total amount of charitable contributions in } 2007 \\
\text { dollars. }\end{array}$ & 1526.86 & 3754.57 \\
\hline Health status & $\begin{array}{l}=5 \text { if health status of household head is excellent, }=4 \\
\text { if it is very good, }=3 \text { if it is good, }=2 \text { if it is fair, and } \\
=1 \text { if it is poor. }\end{array}$ & 3.669 & 1.045 \\
\hline After-tax price & $\begin{array}{l}=1 \text { minus marginal tax rate for itemizers and } 1 \text { for } \\
\text { non itemizers. Marginal tax rates are calculated using } \\
\text { NBER TAXSIM calculator. }\end{array}$ & 0.879 & 0.144 \\
\hline Subsidy & $=1$ minus after-tax price. & 0.121 & 0.144 \\
\hline Income & Total household income in 2007 dollars. & 78438.31 & 109143.20 \\
\hline \multicolumn{4}{|c|}{ Control variables } \\
\hline Family size & $\begin{array}{l}\text { Number of people in the household including the } \\
\text { respondent. }\end{array}$ & 2.547 & 1.342 \\
\hline Children & $\begin{array}{l}\text { Number of children in the household, } 18 \text { years old and } \\
\text { younger. }\end{array}$ & 0.709 & 1.053 \\
\hline Age & Age of the household head. & 45.97 & 16.45 \\
\hline Female & $=1$ if the household head is female. & 0.229 & 0.420 \\
\hline Employed & $=1$ if the household head is employed. & 0.765 & 0.424 \\
\hline Married & $=1$ if the household head is married. & 0.582 & 0.493 \\
\hline Widowed & $=1$ if the household head is widowed. & 0.067 & 0.250 \\
\hline Divorced & $=1$ if the household head is divorced. & 0.145 & 0.352 \\
\hline Separated & $=1$ if the household head is separated. & 0.028 & 0.165 \\
\hline Homeowner & $=1$ if the household head is a homeowner. & 0.683 & 0.466 \\
\hline High school & $\begin{array}{l}=1 \text { if the highest level of education obtained by the } \\
\text { respondent is a high school degree. }\end{array}$ & 0.442 & 0.497 \\
\hline College & $\begin{array}{l}=1 \text { if the respondent obtained a four-year college or } \\
\text { higher degree. }\end{array}$ & 0.422 & 0.494 \\
\hline Graduate & $=1$ if the respondent obtained a graduate degree. & 0.107 & 0.309 \\
\hline Black & $=1$ if the respondent is black. & 0.086 & 0.281 \\
\hline White & $=1$ if the respondent is white. & 0.886 & 0.318 \\
\hline
\end{tabular}

Notes: Mean and standard deviation for key variables are reported for the SRC sample. Total number of observations for self-reported health status is 17957. Total number of observations for the rest of the variables is 17970. Logs of Contribution, After-tax price, and Income are used in the empirical analysis. In addition to the control variables listed in this table, all regressions also control for squared of age variable. 
Table 2. Distribution of health status by gender, race, and marital status

\begin{tabular}{lccccc}
\hline & \multicolumn{5}{c}{ Health status } \\
\cline { 2 - 6 } & Excellent & Very good & Good & Fair & Poor \\
\hline Full sample & 23.70 & 35.92 & 27.38 & 9.58 & 3.41 \\
Female & 15.15 & 33.57 & 32.69 & 13.60 & 4.99 \\
Male & 26.24 & 26.62 & 25.81 & 8.39 & 2.95 \\
White & 24.39 & 36.80 & 26.51 & 8.96 & 3.34 \\
Black & 15.17 & 27.28 & 36.10 & 16.02 & 4.54 \\
Married & 26.59 & 37.52 & 24.98 & 8.09 & 2.82 \\
Unmarried & 19.68 & 33.69 & 30.73 & 11.66 & 4.24 \\
\hline
\end{tabular}

Notes: Percent of household heads who reported excellent, very good, good, fair, or poor health is reported for the full sample and by gender, race, and marital status. 
Table 3. The effect of charitable subsidies on health status

\begin{tabular}{lccc}
\hline & No. of Obs. & Subsidy & $\begin{array}{c}\text { Elasticity wrt } \\
\text { after-tax price }\end{array}$ \\
\hline Full sample & 17956 & $\begin{array}{c}0.367 \\
(0.080)^{* * *}\end{array}$ & $\begin{array}{c}-0.126 \\
(0.028)^{* * *}\end{array}$ \\
Male & 13845 & 0.317 & -0.111 \\
& & $(0.089)^{* * *}$ & $(0.033)^{* * *}$ \\
Female & 4111 & 0.512 & -0.159 \\
& & $(0.185)^{* * *}$ & $(0.060)^{* * *}$ \\
White & 15908 & 0.341 & -0.117 \\
& & $(0.084)^{* * *}$ & $(0.030)^{* * *}$ \\
Black & 1543 & 0.513 & -0.157 \\
& & $(0.326)$ & $(0.103)$ \\
Unmarried & 7503 & 0.403 & -0.134 \\
& & $(0.128)^{* * *}$ & $(0.043)^{* * *}$ \\
\hline
\end{tabular}

Notes: In all models, the dependent variable is self-reported health status index. In column one, the effect of the tax subsidy for charitable giving on self-reported health status is reported. In column two, the elasticity of self-reported health status with respect to the after-tax price of giving is reported. All regressions include a set of control variables as presented in Table 1 and state and year fixed effects. Standard errors are clustered at the household level reported in parentheses. The sign $* * *$ represents statistical significance at $1 \%$ significance level. 
Table 4. The effect of charitable subsidies on health status: Alternative models

\begin{tabular}{lccccc}
\hline & \multicolumn{2}{c}{ Probit } & & \multicolumn{2}{c}{ Ordered Probit } \\
\cline { 2 - 3 } \cline { 5 - 6 } Health Status & Subsidy & After-tax price & & Subsidy & After-tax price \\
\hline Excellent & 0.082 & -0.069 & & 0.121 & -0.098 \\
& $(0.034)^{* *}$ & $(0.028)^{* *}$ & & $(0.027)^{* * *}$ & $(0.022)^{* * *}$ \\
Very Good & 0.064 & -0.045 & & 0.043 & -0.035 \\
& $(0.038)^{*}$ & $(0.031)$ & & $(0.010)^{* * *}$ & $(0.008)^{* * *}$ \\
Good & -0.098 & 0.084 & & -0.091 & 0.073 \\
& $(0.035)^{* * *}$ & $(0.029)^{* * *}$ & & $(0.020)^{* * *}$ & $(0.017)^{* * *}$ \\
Fair & -0.060 & 0.048 & & -0.057 & 0.046 \\
& $(0.021)^{* * *}$ & $(0.018)^{* * *}$ & & $(0.013)^{* * *}$ & $(0.010)^{* * *}$ \\
Poor & -0.031 & 0.026 & & -0.017 & 0.014 \\
& $(0.007)^{* * *}$ & $(0.006)^{* * *}$ & & $(0.004)^{* * *}$ & $(0.003)^{* * *}$ \\
\hline
\end{tabular}

Notes: Marginal effects are reported for all models for the full sample. The number of observations in all regressions is 17956. In columns one and three, the effect of the tax subsidy for charitable giving on self-reported health status is reported. In columns two and four, the effect of $\log$ (after-tax price of giving) on self-reported health status is reported. In the first two columns, results from probit models that are estimated for each individual health outcome are reported. In the last two columns, the dependent variable is self-reported health status index and results from ordered probit models are reported. All regressions include a set of control variables as presented in Table 1 and state and year fixed effects. Standard errors are clustered at the household level and reported in parentheses. The signs $*, * *$, and $* * *$ represent statistical significance at $10 \%$, $5 \%$, and $1 \%$ significance level. 
Table 5. Robustness checks

\begin{tabular}{lccc}
\hline & No. of Obs. & Subsidy & $\begin{array}{c}\text { Elasticity wrt } \\
\text { after-tax price }\end{array}$ \\
\hline $\begin{array}{l}\text { Contol for income distribution } \\
\text { 1. Dummies for the deciles of income }\end{array}$ & 17956 & 0.306 & -0.107 \\
& & $(0.082)^{* * *}$ & $(0.029)^{* * *}$ \\
Income endogeneity & 17941 & 0.347 & -0.120 \\
2. Predicted income & & $(0.078)^{* * *}$ & $(0.028)^{* * *}$ \\
& 17357 & 0.391 & -0.134 \\
3. Fixed income & & $(0.083)^{* * *}$ & $(0.029)^{* * *}$ \\
& & & -0.129 \\
Interaction terms & 17956 & 0.375 & $(0.029)^{* * *}$ \\
4. State/year interactions & & $(0.081)^{* * *}$ & -0.129 \\
& 17956 & 0.373 & $(0.028)^{* * *}$ \\
5. State/income interactions & & $(0.080)^{* * *}$ & -0.125 \\
& 17956 & 0.364 & $(0.028)^{* * *}$ \\
\hline 6. Year/income interactions & & $(0.080)^{* * *}$ & \\
\end{tabular}

Notes: In all models, the dependent variable is self-reported health status index. In column one, the effect of the tax subsidy for charitable giving on self-reported health status is reported. In column two, the elasticity of self-reported health status with respect to the after-tax price of giving is reported. All regressions include a set of control variables as presented in Table 1 and state and year fixed effects. Standard errors are clustered at the household level and reported in parentheses. The sign $* * *$ represents statistical significance at $1 \%$ significance level. 
Table 6 . The effect of charitable subsidies on alternative health outcomes

\begin{tabular}{|c|c|c|c|c|c|c|c|c|c|c|c|}
\hline & Stroke & $\begin{array}{l}\text { High blood } \\
\text { pressure }\end{array}$ & Diabetes & Cancer & $\begin{array}{c}\text { Lung } \\
\text { disease }\end{array}$ & $\begin{array}{l}\text { Heart } \\
\text { attack }\end{array}$ & $\begin{array}{c}\text { Heart } \\
\text { disease }\end{array}$ & $\begin{array}{c}\text { Emotional } \\
\text { problems }\end{array}$ & Arthritis & Asthma & Obese \\
\hline Subsidy & $\begin{array}{c}0.001 \\
(0.006)\end{array}$ & $\begin{array}{c}-0.046 \\
(0.038)\end{array}$ & $\begin{array}{c}-0.023 \\
(0.020)\end{array}$ & $\begin{array}{l}-0.018 \\
(0.014)\end{array}$ & $\begin{array}{c}-0.036 \\
(0.015)^{* *}\end{array}$ & $\begin{array}{l}-0.001 \\
(0.007)\end{array}$ & $\begin{array}{c}0.002 \\
(0.016)\end{array}$ & $\begin{array}{c}-0.039 \\
(0.019)^{* *}\end{array}$ & $\begin{array}{c}-0.070 \\
(0.030)^{* *}\end{array}$ & $\begin{array}{c}0.021 \\
(0.025)\end{array}$ & $\begin{array}{l}-0.058 \\
(0.039)\end{array}$ \\
\hline Pseudo $\mathrm{R}^{2}$ & 0.241 & 0.161 & 0.121 & 0.166 & 0.114 & 0.248 & 0.200 & 0.124 & 0.214 & 0.045 & 0.043 \\
\hline No. of Obs. & 17466 & 17917 & 17798 & 17897 & 17388 & 17891 & 17919 & 17752 & 17916 & 17823 & 17798 \\
\hline
\end{tabular}

Notes: In all models, marginal effects of the subsidy rate on the outcome variables from probit models are reported for the full sample. All regressions include a set of control variables as presented in Table 1 and state and year fixed effects. Standard errors are clustered at the household level and reported in parentheses. The sign ** represents statistical significance at $5 \%$ significance level. 
Table 7. The effect of charitable giving on health status

\begin{tabular}{|c|c|c|c|c|c|c|c|}
\hline & \multirow[b]{3}{*}{ No. of Obs. } & \multicolumn{3}{|c|}{ Probability of giving } & \multicolumn{3}{|c|}{ Contribution amount } \\
\hline & & \multirow{2}{*}{$\frac{\text { OLS }}{\begin{array}{c}\text { Coefficient on } \\
\text { Give }\end{array}}$} & \multicolumn{2}{|c|}{ IV } & \multirow{2}{*}{$\frac{\text { OLS }}{\begin{array}{c}\text { Coefficient on } \\
\log (\text { Contribution })\end{array}}$} & \multicolumn{2}{|r|}{ IV } \\
\hline & & & $\begin{array}{c}\text { Coefficient on } \\
\text { subsidy }\end{array}$ & $\begin{array}{l}\text { Coefficient on } \\
\text { Give }\end{array}$ & & $\begin{array}{l}\text { Coefficient on } \\
\text { subsidy }\end{array}$ & $\begin{array}{c}\text { Coefficient on } \\
\log (\text { Contribution })\end{array}$ \\
\hline Full sample & 17956 & $\begin{array}{c}0.149 \\
(0.022)^{* * *}\end{array}$ & $\begin{array}{c}0.442 \\
(0.027)^{* * *}\end{array}$ & $\begin{array}{c}0.831 \\
(0.187)^{* * *}\end{array}$ & $\begin{array}{c}0.026 \\
(0.003)^{* * *}\end{array}$ & $\begin{array}{c}4.336 \\
(0.185)^{* * *}\end{array}$ & $\begin{array}{c}0.085 \\
(0.019)^{* * *}\end{array}$ \\
\hline Male & 13845 & $\begin{array}{c}0.164 \\
(0.026)^{* * *}\end{array}$ & $\begin{array}{c}0.470 \\
(0.030)^{* * *}\end{array}$ & $\begin{array}{c}0.674 \\
(0.192)^{* * *}\end{array}$ & $\begin{array}{c}0.028 \\
(0.004)^{* * *}\end{array}$ & $\begin{array}{c}4.423 \\
(0.207)^{* * *}\end{array}$ & $\begin{array}{c}0.072 \\
(0.020)^{* * *}\end{array}$ \\
\hline Female & 4111 & $\begin{array}{c}0.109 \\
(0.042)^{* * *}\end{array}$ & $\begin{array}{c}0.486 \\
(0.071)^{* * *}\end{array}$ & $\begin{array}{c}1.053 \\
(0.403)^{* * *}\end{array}$ & $\begin{array}{c}0.022 \\
(0.007)^{* * *}\end{array}$ & $\begin{array}{c}4.572 \\
(0.445)^{* * *}\end{array}$ & $\begin{array}{c}0.112 \\
(0.042)^{* * *}\end{array}$ \\
\hline White & 15908 & $\begin{array}{c}0.153 \\
(0.024)^{* * *}\end{array}$ & $\begin{array}{c}0.431 \\
(0.029)^{* * *}\end{array}$ & $\begin{array}{c}0.790 \\
(0.199)^{* * *}\end{array}$ & $\begin{array}{c}0.026 \\
(0.004)^{* * *}\end{array}$ & $\begin{array}{c}4.117 \\
(0.195)^{* * *}\end{array}$ & $\begin{array}{c}0.083 \\
(0.021)^{* * *}\end{array}$ \\
\hline Black & 1543 & $\begin{array}{c}0.100 \\
(0.062)^{*}\end{array}$ & $\begin{array}{c}0.684 \\
(0.125)^{* * *}\end{array}$ & $\begin{array}{c}0.750 \\
(0.496)^{* * *}\end{array}$ & $\begin{array}{c}0.025 \\
(0.010)^{* * *}\end{array}$ & $\begin{array}{c}7.489 \\
(0.796)^{* * *}\end{array}$ & $\begin{array}{c}0.069 \\
(0.044)^{* * *}\end{array}$ \\
\hline Unmarried & 7503 & $\begin{array}{c}0.152 \\
(0.029)^{* * *}\end{array}$ & $\begin{array}{c}0.587 \\
(0.050)^{* * *}\end{array}$ & $\begin{array}{c}0.686 \\
(0.221)^{* * *}\end{array}$ & $\begin{array}{c}0.027 \\
(0.005)^{* * *}\end{array}$ & $\begin{array}{c}5.023 \\
(0.312)^{* * *}\end{array}$ & $\begin{array}{c}0.080 \\
(0.026)^{* * *}\end{array}$ \\
\hline
\end{tabular}

Notes: Results from OLS and 2SLS models are reported. In all models, the dependent variable is self-reported health index. In 2SLS models, the instrumental variable is the rate of tax subsidy for charitable giving and the endogenous variable is whether the household donated to charity or the natural $\log$ of the amount of its charitable contributions. All regressions include a set of control variables as presented in Table 1 and state and year fixed effects. Standard errors are clustered at the household level and reported in parentheses. The sign $*$ and $* * *$ represents statistical significance at $10 \%$ and $1 \%$ significance level. 
Table 8. The effect of charitable giving on alternative health outcomes

\begin{tabular}{|c|c|c|c|c|c|c|c|c|c|c|c|}
\hline & Stroke & $\begin{array}{l}\text { High blood } \\
\text { pressure }\end{array}$ & Diabetes & Cancer & $\begin{array}{c}\text { Lung } \\
\text { disease }\end{array}$ & $\begin{array}{l}\text { Heart } \\
\text { attack }\end{array}$ & $\begin{array}{c}\text { Heart } \\
\text { disease }\end{array}$ & $\begin{array}{c}\text { Emotional } \\
\text { problems }\end{array}$ & Arthritis & Asthma & Obese \\
\hline Give & $\begin{array}{c}0.013 \\
(0.029)\end{array}$ & $\begin{array}{c}-0.134 \\
(0.082)^{*}\end{array}$ & $\begin{array}{l}-0.069 \\
(0.055)\end{array}$ & $\begin{array}{l}-0.062 \\
(0.043)\end{array}$ & $\begin{array}{c}-0.064 \\
(0.036)^{*}\end{array}$ & $\begin{array}{c}-0.035 \\
(0.043)\end{array}$ & $\begin{array}{c}-0.017 \\
(0.048)\end{array}$ & $\begin{array}{l}-0.026 \\
(0.046)\end{array}$ & $\begin{array}{c}-0.179 \\
(0.069)^{* * *}\end{array}$ & $\begin{array}{c}0.070 \\
(0.056)\end{array}$ & $\begin{array}{c}-0.124 \\
(0.088)\end{array}$ \\
\hline $\log ($ Contribution $)$ & $\begin{array}{c}0.001 \\
(0.003)\end{array}$ & $\begin{array}{c}-0.014 \\
(0.008)^{*}\end{array}$ & $\begin{array}{l}-0.007 \\
(0.006)\end{array}$ & $\begin{array}{c}-0.006 \\
(0.004)\end{array}$ & $\begin{array}{c}-0.007 \\
(0.004)^{*}\end{array}$ & $\begin{array}{c}-0.004 \\
(0.004)\end{array}$ & $\begin{array}{c}-0.002 \\
(0.005)\end{array}$ & $\begin{array}{c}-0.003 \\
(0.005)\end{array}$ & $\begin{array}{c}-0.018 \\
(0.007)^{* * *}\end{array}$ & $\begin{array}{c}0.007 \\
(0.006)\end{array}$ & $\begin{array}{l}-0.013 \\
(0.009)\end{array}$ \\
\hline No. of Obs. & 17954 & 17953 & 17956 & 17955 & 17954 & 17955 & 17955 & 17955 & 17952 & 17957 & 17798 \\
\hline
\end{tabular}

Notes: Results from 2SLS models are reported for the full sample. In all models, the instrumental variable is the rate of tax subsidy for charitable giving. The endogenous variables are whether the household donated to charity or the natural log of the amount of its charitable contributions. All regressions include a set of control variables as presented in Table 1 and state and year fixed effects. Standard errors are clustered at the household level and reported in parentheses. The signs $*$ and $* * *$ represents statistical significance at $10 \%$ and $1 \%$ significance levels, respectively. 